\title{
Anthropic pollen indicators: poaceae pollen of non- native species in Southern Brazil
}

\begin{abstract}
The Poaceae species have their use for food known in Brazil and in the world. Maize, which today accounts for $21 \%$ of human nutrition, was changed 9,000 years ago from Teosinte. Many indigenous people grow maize in South America to feed the tribe. In Brazil, several Poaceae species of African origin were introduced accidentally purposely in the colonial period, to be used as fodder, as was the case of annoni grass (Eragrostis plana Nees). Palynological studies may reconstitute a vegetation of the past, but due to the similarity of Poaceae pollen grains, so far maize (Zea mays L.) can be identified with the safety of the palynological studies. The aim of the study here is to identify and describe the pollen grains of Poaceae exotic cultivated species. The pollen grains were collected from herborized plants and processed by usual techniques of palynology (acetolysis). The results allow identification of three pollen groups (pollen of ornamental, cereal and corn plants). Pollen morphology of 14 species of exotic Poaceae in Rio Grande do Sul state showed differences in sizes of pollen grains. The results of this research showed that cultivars of grasses can be identified in sedimentary profiles. However, some pollen grains have the size of pollen similar to Poaceae pollen of native species. Thus, it is necessary knowledge about the vegetation of study area and surrounds distributed cultivars of grasses. Nevertheless, this pollen database is important to mapping with more precision the cultivation of these cereals in the Late Holocene.
\end{abstract}

Keywords: palynology, grasses, human occupation

\section{Introduction}

The identification of environmental changes by human action in the past is crucial for recovery plans and preservation of natural areas. Changes of the landscape (by human action) and natural shifts of vegetation can be showed by pollen records analysis. In this sense, pollen description of modern plants is important for use as a database for the identification of pollen samples of past. The indigenous human occupation is indicated, principally, by high concentrations of carbonized particles (linked to fire management) and a decrease of the percentage of pollen of forest species in the Quaternary sediments. While the occupation by post-Columbian settlers is indicated by pollen grains of crops or species to the plantation, such as Pinus
Volume 2 Issue 2 - 2018

\section{Jefferson Nunes Radaeski,Andreia Cardoso Pacheco Evaldt, Soraia Girardi Bauermann} Laboratório de Palinologia da Universidade Luterana do BrazilULBRA, Universidade Luterana do Brazil, Brazil

\section{Correspondence: Jefferson Nunes Radaeski, Laboratório} de Palinologia da Universidade Luterana do Brazil-ULBRA, Universidade Luterana do Brazil, Brazil,Tel +55-(5I)-34774000, Email jefferson.radaeski@gmail.com

Received: March 12, 2018 | Published: April 03, 2018
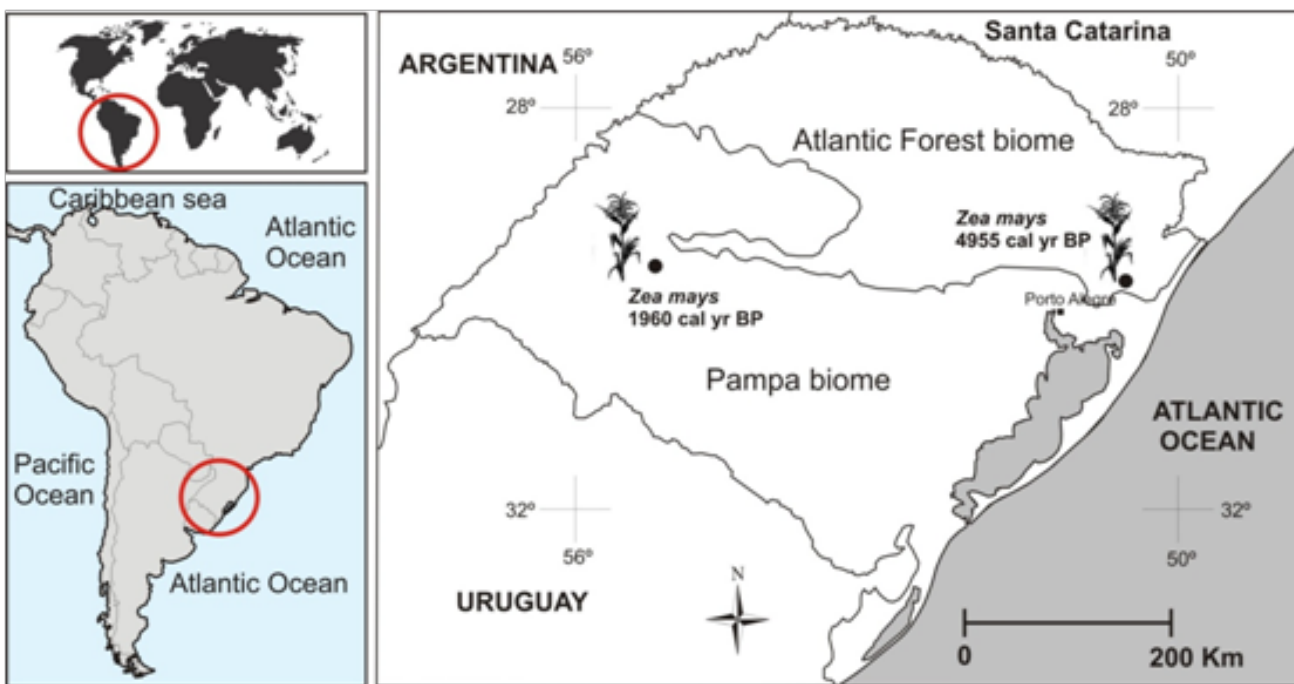

Figure I Pollen grains records of Zea mays (corn) in Quaternary sediments of Rio Grande do Sul state and the ages what the pollen of Zea mays were founded in the sediment according to. ${ }^{47}$

sp. and Eucalyptus sp. ${ }^{1}$ In southern Brazil, these pollen indicators are recorded at least $2.000 \mathrm{BP}^{2-6}$ However, the corn is the only crop species of grasses recorded (Figure 1) in the Quaternary samples of the region..$^{4-7}$ Many species of crops belong to Poaceae family. However, the distinction of pollen grains of native and crop species is difficult due to uniform pollen morphology of Poaceae species, except the pollen of corn that has size very large. ${ }^{8,9}$ The pollen morphology of many crop and native species are analyzed in the Europe continent. ${ }^{10}$ Based on the measurements of the pollen grains, the authors were able to distinguish between cereal and native pollen grains..$^{10}$ On the other hand, other cultivated species such as ryegrass (Lolium multiflorum) have pollen grains that cannot be distinguished from native Brazilian taxa. ${ }^{11,12}$ 
The other studies on pollen grains of cultivated grasses focused on the analysis of the exine surfaces by scanning electron microscopy of species of rice-Oryza, ${ }^{13,14}$ sugar cane-Saccharum,${ }^{15}$ oat-Avena ${ }^{14-17}$ and wheat-Triticum. ${ }^{14-18}$ In some cases, morphotypes were proposed based on the ornamentation observed in scanning electron microscopy. ${ }^{14}$ However, for the analysis of the pollen grains in the sediments is difficult to use scanning electron microscopy, since the sample set of palynomorphs is large. Thus, data with parameters compatible with the identification of palynomorphs are required. In the last decade, deepening pollen analyzes in native Poaceae species have provided ecological inferences for application to pollen records. ${ }^{19-23}$ These modern Poaceae pollen database allowed analysis of Poaceae pollen grains of Quaternary sediments that showed dynamics of grasslands vegetation in the past. ${ }^{24}$ Even so, gaps still have to be filled on the pollen morphology of species of this family introduced in South America to more accurately identify the human occupation in the region during the Holocene. The pollen grains of the 14 main nonnative species of Poaceae distributed in the Rio Grande do Sul were analyzed in order to record possible human occupation indicators for quaternary samples from southern Brazil. Pollen data of non-native grasses will be compared with the data of native Poaceae pollen contained in the works of Radaeski (2015). ${ }^{21-25}$

\section{Overview of human occupation in rio grande do sul}

In South America occupations of several regions occurred during the end of the Pleistocene and beginning of the Holocene verified by archaeological data. ${ }^{26}$ Since the beginning of the Holocene (between 10.800 and 10.200 years BP), already occurred occupations of the first humans near the Uruguay River and in areas of open vegetation of the Pampa biome (southwest of Rio Grande do Sul), but these people of the Umbu tradition did not use crops to survive and were huntergatherers. ${ }^{26-30}$ People of this same tradition also occupied the Atlantic Forest in the northeastern part of the State with dates between 8.790 and 8.090 years BP. ${ }^{26}$ Around 2.000 years BP, several people who used the crop of maize occupied regions mainly in the north and east of Rio Grande do Sul. The first sambaquis appeared around 3.950 years BP with the occupation of the Coast Plain. In this same period, people of the Tupiguarani tradition with economies based on diverse cultures, including corn, settled in subtropical forests in the northwest of the State. ${ }^{29}$ Between the II and XII centuries, the Guatambu phase predominated in the northern region of Rio Grande do Sul using as a resource the collection of seeds of Araucaria angustifolia, the hunt and tropical crops such as maize, cassava and sweet potatoes. ${ }^{29}$ From the XVI century began the expansions of European colonization on the territory of the State and, with this, the introduction of new species cultivated in the region. ${ }^{31}$ The palynological data corroborate with the archaeological information attesting to the occurrence of maize around 4.955 years BP in the Coastal Plain and in 1.960 AP years BP in the Pampa biome. ${ }^{4-7}$

\section{Material and methods}

\section{Treatment of samples}

The plants collected (Figure 2) were dehydrated and the herborized plants deposited in the Herbário do Museu de Ciências Naturais da Ulbra (MCN/HERULBRA). Some pollen samples were collected from plants deposited in HERULBRA and ICN of UFRGS. The anthers extracted from the plants were processed according to the technique of acetolysis of Erdtman (1952). ${ }^{32}$ Slides were mounted with glycerinated jelly and deposited in the Palynotheca of Laboratório de
Palinologia da Ulbra. The diameter of pollen (D), pore and annulus were measured, as well as, the exine thickness $(\mathrm{Ex}) .{ }^{25}$ pollen grains were measured for each species using a 1000x magnification. The pollen descriptions followed the terminology proposed by ${ }^{33,34}$ and are organized in an evolutionary order according to. ${ }^{35}$

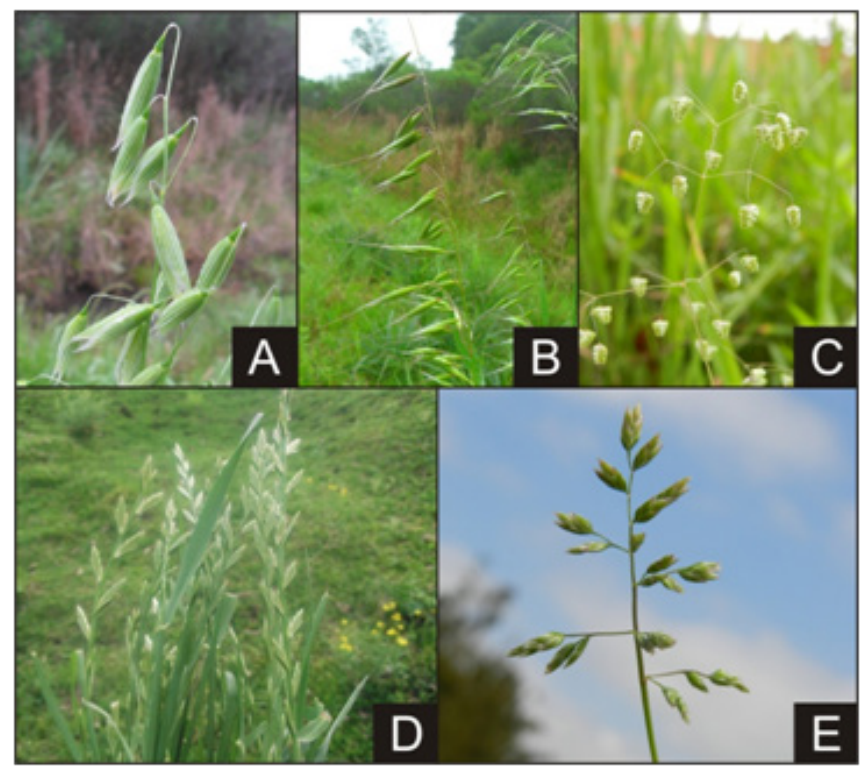

Figure 2 Non-native species of Poaceae. "Aveia” - Avena sativa (A), "Aveiapreta" - Avena strigosa (B), "Capim treme-treme" - Briza minor (C), "Azevém” - Lolium multiflorum (D) and "Pé-de-galinha" - Poa annua (E).

\section{Results}

The morphological descriptions of 14 non-native species of the Poaceae family occurring in the Rio Grande do Sul are shown. All species presented pollen grains with the spherical shape and monoporate aperture, but variations in pollen grain sizes, ornamentation, and size of the aperture were observed.

Subfamily: Oryzoideae

Tribe: Oryzeae

Oryza sativa $\mathrm{L}$.

Common name: "arroz"

Figure 3(A-D) Monad, medium size of pollen grain, radial symmetry, heteropolar, circular amb, spheroidal, monoporate, pore circular with annulus (diameter of $5 \mu \mathrm{m}$ located in distal pole), diameter of annulus of $13 \mu \mathrm{m}$ and thickness of $4 \mu \mathrm{m}$ with ornamented surface, exina tectate, columellate with microechinate ornamentation. Sexine with $0,8 \mu \mathrm{m}$ and nexine of the same thickness. D: $49 \mu \mathrm{m}$ (4557); Ex: 1,6 $\mu \mathrm{m}$.

Plant information: BRASIL, Rio Grande do Sul: Glorinha, 15.III.2012, L. Bubols (HERULBRA 4490). Slide of reference: P-1426.

Ecological information: Genus with two non-native species. Oryza sativa (rice) cultivated as food originates in Asia and Oryza rufipogon, known as wild rice, is invasive of rice crops. ${ }^{36}$ In Brazil, the presence of rice dates back to the time of discovery of this country. This cereal was included in the menu of the discoverers and was also used in feeding the local populations. ${ }^{37}$ 
Subfamily: Pooideae

Tribe: Poeae

Avena sativa $\mathrm{L}$.

Common name: "aveia"

Figure 3(E-H) Monad, medium size of pollen grain, radial symmetry, heteropolar, circular amb, spheroidal, monoporate, pore circular with annulus (diameter of $4 \mu \mathrm{m}$ located in distal pole), diameter of annulus of $11 \mu \mathrm{m}$ and thickness of $3,5 \mu \mathrm{m}$ with ornamented surface, exina tectate, columellate with microechinate ornamentation. Sexine with $0,6 \mu \mathrm{m}$ and nexine of the same thickness. D: $41 \mu \mathrm{m}$ (37-48); Ex: $1,2 \mu \mathrm{m}$.

Plant information: BRASIL, Rio Grande do Sul: Gravataí, Sitio Osvaldo, 14.IX.2013, J.N. Radaeski (HERULBRA 4858). Slide of reference: P-1452.

Ecological information: Genus with six non-native species from Europe. Some species are used for seed grains crops. ${ }^{36}$ In Brazil, until the early 1980, the cultivars of white oats came from Argentina and Uruguay. After this age, Brazilian white oat cultivars with cycle and height adapted for production were distributed in southern Brazil. ${ }^{37}$

Subfamily: Avena strigosa Schreb.

Common name: "aveia-preta"

Figure 3(I-J) Monad, medium to large size of pollen grain, radial symmetry, heteropolar, circular amb, spheroidal, monoporate, pore circular with annulus (diameter of $5 \mu \mathrm{m}$ located in distal pole), diameter of annulus of $12 \mu \mathrm{m}$ and thickness of 3,5 $\mu \mathrm{m}$ with ornamented surface, exina tectate, columellate with microechinate ornamentation. Sexine with $0,52 \mu \mathrm{m}$ and nexine of the same thickness. D: $47 \mu \mathrm{m}$ (4153); Ex: 1,04 $\mu \mathrm{m}$.

Plant information: BRASIL, Rio Grande do Sul: Caçapava do Sul, 30.IX.2014, S.G. Bauermann \& J.N. Radaeski (HERULBRA 4867). Slide of reference: P-1607.

Ecological information: Species of this genus are widely used for cultivation of their grains, and Avena strigosa is also used for fodder for its resistance to pests. ${ }^{36}$

Subfamily: Briza minor L.

Common name: "capim-treme-treme"

Figure 3(M-P)

Monad, small to medium size of pollen grain, radial symmetry, heteropolar, circular amb, spheroidal, monoporate, pore circular with annulus (diameter of $2 \mu \mathrm{m}$ located in distal pole), diameter of annulus of $6 \mu \mathrm{m}$ and thickness of $2 \mu \mathrm{m}$ with ornamented surface, exina tectate, columellate with microechinate ornamentation. Sexine with $0,5 \mu \mathrm{m}$ and nexine of the same thickness. D: $24 \mu \mathrm{m}$ (22-26); Ex: $1 \mu \mathrm{m}$.

Plant information: BRASIL, Rio Grande do Sul: Caçapava do Sul, 30.IX.2014, S.G. Bauermann \& J.N. Radaeski (HERULBRA 4869). Slide of reference: P-1609.

Ecological information: Specie originating in Europe used as ornamental. ${ }^{36}$

Subfamily: Holcus lanatus L.

\section{Common name: "capim-lanudo"}

Figure 3(Q-T)

Monad, small to medium size of pollen grain, radial symmetry, heteropolar, circular amb, spheroidal, monoporate, pore circular with annulus (diameter of $2 \mu \mathrm{m}$ located in distal pole), diameter of annulus of $6 \mu \mathrm{m}$ and thickness of $2 \mu \mathrm{m}$ with ornamented surface, exina tectate, columellate with microechinate ornamentation. Sexine with $0,5 \mu \mathrm{m}$ and nexine of the same thickness. D: $25 \mu \mathrm{m}$ (23-28); Ex: $1 \mu \mathrm{m}$.

Plant information: BRASIL, Rio Grande do Sul: Caxias do Sul, 01.III.1965, K. Hagelund, 3797 (ICN 140174). Slide of reference: P-1544.

Ecological information: Genus with only a sub-spontaneous species originating in Europe that occurs in the State mainly in cold regions being used as fodder. ${ }^{36-38}$
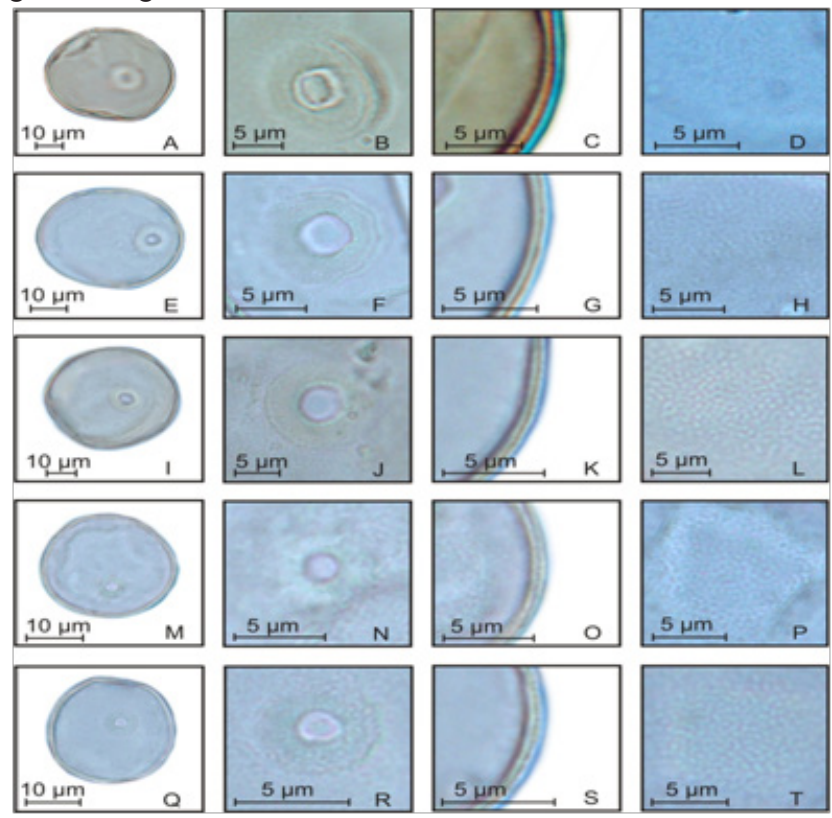

Figure 3 Poaceae pollen grains of non-native species of the Rio Grande do Sul. Oryza sativa: Pollen grain (A), detail of aperture (B), detail of exine (C), detail of ornamentation (D); Avena sativa: Pollen grain (E), detail of aperture $(\mathrm{F})$, detail of exine $(\mathrm{G})$, detail of ornamentation $(\mathrm{H})$; Avena strigosa: Pollen grain (I), detail of aperture $(\mathrm{J})$, detail of exine $(\mathrm{K})$, detail of ornamentation $(\mathrm{L})$; Briza minor: Pollen grain $(M)$, detail of aperture $(N)$, detail of exine $(O)$, detail of ornamentation $(\mathrm{P})$; Holcus lanatus: Pollen grain $(\mathrm{Q})$, detail of aperture $(\mathrm{R})$, detail of exine $(S)$, detail of ornamentation $(T)$.

Subfamily: Poa annua L.

Common name: "pé-de-galinha", "pastinho-de-inverno"

Figure 4(A-D)

Monad, medium size of pollen grain, radial symmetry, heteropolar, circular amb, spheroidal, monoporate, pore circular with annulus (diameter of $3 \mu \mathrm{m}$ located in distal pole), diameter of annulus of 8 $\mu \mathrm{m}$ and thickness of 2,5 $\mu \mathrm{m}$ with ornamented surface, exina tectate, columellate with microechinate ornamentation. Sexine with $0,5 \mu \mathrm{m}$ and nexine of the same thickness. D: $25 \mu \mathrm{m}$ (22-27); Ex: $1 \mu \mathrm{m}$.

Plant information: BRASIL, Rio Grande do Sul: São Gabriel, Cerro do Ouro, 03.X.2013, J.N. Radaeski (HERULBRA 4857). Slide of reference: P-1451. 
Ecological information: Genus with six species, five of which are native to the State distributed in the grassland vegetation. ${ }^{36,39}$ Poa annua is originally from Europe with large distribution in the State living mainly in altered regions. ${ }^{36}$

Subfamily: Lolium multiflorum L.

Common name: "azevém"

Figure 4(E-H)

Monad, medium size of pollen grain, radial symmetry, heteropolar, circular amb, spheroidal, monoporate, pore circular with annulus (diameter of $3 \mu \mathrm{m}$ located in distal pole), diameter of annulus of 9 $\mu \mathrm{m}$ and thickness of $3 \mu \mathrm{m}$ with ornamented surface, exina tectate, columellate with microechinate ornamentation. Sexine with $0,5 \mu \mathrm{m}$ and nexine of the same thickness. D: $35 \mu \mathrm{m}(30-40)$; Ex: $1 \mu \mathrm{m}$.

Plant information: BRASIL, Rio Grande do Sul: Gravataí, Sitio Osvaldo, 14.IX.2013, J.N. Radaeski (HERULBRA 4856). Slide of reference: P-1490.

Ecological information: Genus with three non-native species of European origin. Lolium multiflorum lives in humid places because this specie presents great tolerance to excess moisture, besides grazing. ${ }^{36}$

\section{Subfamily: Lolium temulentum L.}

Common name: "joio"

Figure 4(I-L)

Monad, medium size of pollen grain, radial symmetry, heteropolar, circular amb, spheroidal, monoporate, pore circular with annulus (diameter of $3 \mu \mathrm{m}$ located in distal pole), diameter of annulus of 9 $\mu \mathrm{m}$ and thickness of $3 \mu \mathrm{m}$ with ornamented surface, exina tectate, columellate with microechinate ornamentation. Sexine with $0,52 \mu \mathrm{m}$ and nexine of the same thickness. D: $32 \mu \mathrm{m}$ (27-38); Ex: 1,04 $\mu \mathrm{m}$.

Plant information: BRASIL, Rio Grande do Sul: Caçapava do Sul, 30.IX.2014, S.G. Bauermann \& J.N. Radaeski (HERULBRA 4870). Slide of reference: P-1610.

Ecological information: An annual species that contains toxic alkaloids and is poor common in Rio Grande do Sul. ${ }^{36}$

Subfamily: Secale cereale $\mathrm{L}$.

\section{Tribe: Triticeae}

Common name: "centeio"

Figure 4(M-P)

Monad, medium size of pollen grain, radial symmetry, heteropolar, circular amb, spheroidal, monoporate, pore circular with annulus (diameter of $4 \mu \mathrm{m}$ located in distal pole), diameter of annulus of 11 $\mu \mathrm{m}$ and thickness of 3,5 $\mu \mathrm{m}$ with ornamented surface, exina tectate, columellate with microechinate ornamentation. Sexine with $0,52 \mu \mathrm{m}$ and nexine of the same thickness. D: $49 \mu \mathrm{m}$ (45-54); Ex: 1,04 $\mu \mathrm{m}$.

Plant information: BRASIL, Rio Grande do Sul: Porto Alegre, X.1924 (ICN 24035). Slide of reference: P-1474.

Ecological information: Tribe with non-native genera, except the genus Hordeum which has native species. A cultivated species originating in Africa popularly known as rye. Resistant to cold and drought due to their deep roots [36]. Rye arrived in the Americas, probably from Europe, around the XV or XVI. Only during the centuries XIX and XX is that rye was introduced in South America, initially in Argentina, Uruguay and southern Brazil. ${ }^{37}$

Subfamily: Triticum sp. L.

Common name: "trigo"

Figure 4(Q-T)

Monad, large size of pollen grain, radial symmetry, heteropolar, circular amb, spheroidal, monoporate, pore circular with annulus (diameter of $7 \mu \mathrm{m}$ located in distal pole), diameter of annulus of 19 $\mu \mathrm{m}$ and thickness of $6 \mu \mathrm{m}$ with ornamented surface, exina tectate, columellate with microechinate ornamentation. Sexine with $0,52 \mu \mathrm{m}$ and nexine of the same thickness. D: $43 \mu \mathrm{m}$ (35-50); Ex: $2 \mu \mathrm{m}$.

Plant information: BRASIL, Rio Grande do Sul: São Miguel das Missões, 10.X.2009, S.G. Slide of reference: P-1077.

Ecological information: Species of the Triticum genus are grown in the State for food purposes such as flour, breads and beverages. ${ }^{36}$ In South America wheat was sown for the first time in 1527, in the current Province of Santa Fé in Argentina. In Brazil wheat was introduced in 1534, and expanded from the Captaincy of São Vicente to other regions of the country accompanying the work of catechesis carried out by religious missions. ${ }^{37}$
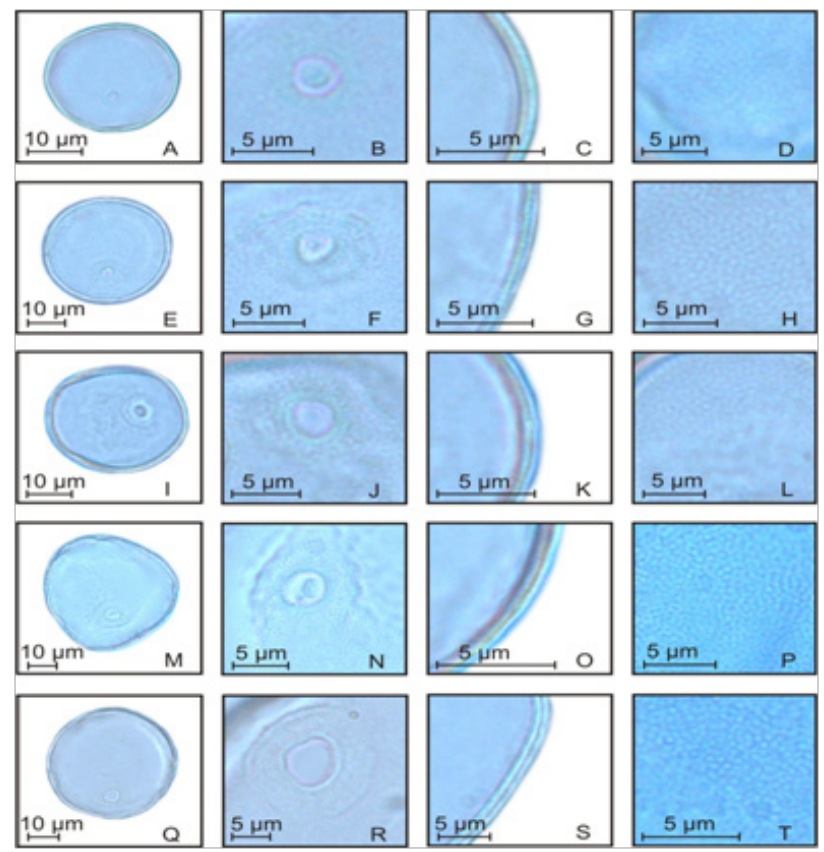

Figure 4 Poaceae pollen grains of non-native species of the Rio Grande do Sul. Poa annua: Pollen grain (A), detail of aperture (B), detail of exine (C), detail of ornamentation (D); Lolium multiflorum: Pollen grain (E), detail of aperture (F), detail of exine $(\mathrm{G})$, detail of ornamentation $(\mathrm{H})$; Lolium temulentum: Pollen grain (I), detail of aperture $(\mathrm{J})$, detail of exine $(\mathrm{K})$, detail of ornamentation $(\mathrm{L})$; Secale cereale: Pollen grain $(\mathrm{M})$, detail of aperture $(\mathrm{N})$, detail of exine $(\mathrm{O})$, detail of ornamentation (P); Triticum sp.: Pollen grain (Q), detail of aperture $(\mathrm{R})$, detail of exine (S), detail of ornamentation $(\mathrm{T})$.

Subfamily: Panicoideae

Tribe: Paniceae

Cenchrus clandestinus (Hochst. ex Chiov.) Morrone 


\section{Common name: kikuio}

Figure 5(A-D)

Monad, medium size of pollen grain, radial symmetry, heteropolar, circular amb, spheroidal, monoporate, pore circular with annulus (diameter of $4 \mu \mathrm{m}$ located in distal pole), diameter of annulus of 11 $\mu \mathrm{m}$ and thickness of $3,5 \mu \mathrm{m}$ with ornamented surface, exina tectate, columellate with microechinate ornamentation. Sexine with $0,65 \mu \mathrm{m}$ and nexine of the same thickness. D: $44 \mu \mathrm{m}$ (40-49); Ex: 1,3 $\mu \mathrm{m}$.

Plant information: BRASIL, Rio Grande do Sul: São Gabriel, Cerro do Ouro, 03.X.2013, J.N. Radaeski (HERULBRA 4853). Slide of reference: P-1455.

Ecological information: Genus with one native species and three non-native species. Cenchrus clandestinus is an aggressive species to crops. ${ }^{36}$

Subfamily: Urochloa arrecta (Hack. ex T.Durand \& Schinz) Morrone \& Zuloaga

Common name: "braquiária-do-brejo"

Figure 5(E-H)

Monad, medium size of pollen grain, radial symmetry, heteropolar, circular amb, spheroidal, monoporate, pore circular with annulus (diameter of $3 \mu \mathrm{m}$ located in distal pole), diameter of annulus of 8 $\mu \mathrm{m}$ and thickness of $2,5 \mu \mathrm{m}$ with ornamented surface, exina tectate, columellate with microechinate ornamentation. Sexine with $0,5 \mu \mathrm{m}$ and nexine of the same thickness. D: $33 \mu \mathrm{m}$ (29-37); Ex: $1 \mu \mathrm{m}$.

Plant information: BRASIL, Rio Grande do Sul: Santo Antônio da Patrulha, 17.XI.2005, I. Boldrini \& R. Trevisan 1436a (ICN 149021). Slide of reference: P-1598.

Ecological information: Genus with six non-native species of African origin. Urochloa arrecta is an invasive species with a common occurrence on the coast of the State. ${ }^{36}$ Initially it was introduced as pasture for flooded areas and today it presents importance as weed. ${ }^{40}$

Subfamily: Zea mays L.

Tribe: Andropogoneae

Common name: "milho"

Figure 5(I-L)

Monad, very large size of pollen grain, radial symmetry, heteropolar, circular amb, spheroidal, monoporate, pore circular with annulus (diameter of $9 \mu \mathrm{m}$ located in distal pole), diameter of annulus of $20 \mu \mathrm{m}$ and thickness of 5,5 $\mu \mathrm{m}$ with ornamented surface, exina tectate, columellate with microechinate ornamentation. Sexine with $1,75 \mu \mathrm{m}$ and nexine of the same thickness. D: $101 \mu \mathrm{m}$ (88-122); Ex: $3,5 \mu \mathrm{m}$.

Plant information: BRASIL, Rio Grande do Sul: Itacurubi, 12.XII.2009, S.G. Bauermann et al. $s / n^{o}$ (HERULBRA 4316). Slide of reference: P-1165.

Ecological information: Genus with an exotic cultivated species that lives from dry to moist soils. ${ }^{36}$ The estimated age of corn is 11 million years and their origin and distribution indicate Mexico. ${ }^{37}$ However the date of his arrival in Brazil is still not well defined.

Subfamily: Chloridoideae
Tribe: Eragrostideae

Eragrostis plana Nees

Common name: "capim-annoni"

Figure 5(M-P)

Monad, small to medium size of pollen grain, radial symmetry, heteropolar, circular amb, spheroidal, monoporate, pore circular with annulus (diameter of $3 \mu \mathrm{m}$ located in distal pole), diameter of annulus of $9 \mu \mathrm{m}$ and thickness of $3 \mu \mathrm{m}$ with ornamented surface, exina tectate, columellate with microechinate ornamentation. Sexine with $0,52 \mu \mathrm{m}$ and nexine of the same thickness. D: $26 \mu \mathrm{m}$ (22-30); Ex: 1,04 $\mu \mathrm{m}$.

Plant information: BRASIL, Rio Grande do Sul: Itacurubi, 17.XII.2009, S.G. Bauermann et al. (HERULBRA 4454). Slide of reference: P-1259.

Ecological information: O "capim-annoni-2", Eragrostis plana Nees, is a tropical, perennial, summer, non-native Poaceae, originating in Africa, introduced accidentally in Brazil as a contaminant of imported seeds, in the $1950{ }^{41}$
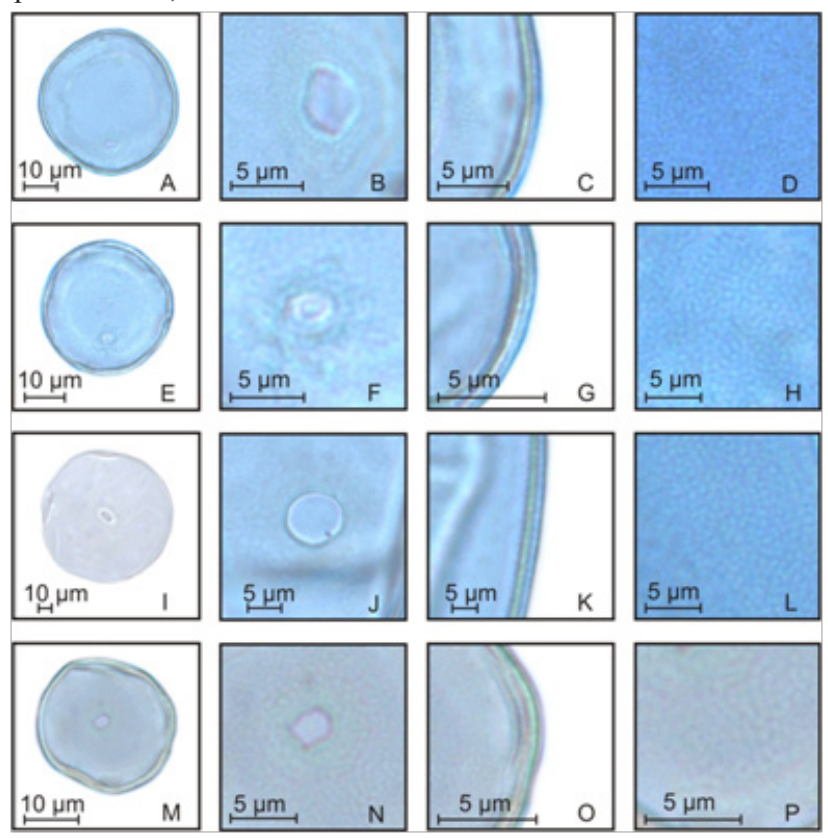

Figure 5 Poaceae pollen grains of non-native species of the Rio Grande do Sul. Cenchrus clandestinus: Pollen grain (A), detail of aperture (B), detail of exine (C), detail of ornamentation (D); Urochloa arrecta: Pollen grain (E), detail of aperture $(\mathrm{F})$, detail of exine $(\mathrm{G})$, detail of ornamentation $(\mathrm{H})$; Zea mays: Pollen grain $(\mathrm{I})$, detail of aperture $(\mathrm{J})$, detail of exine $(\mathrm{K})$, detail of ornamentation $(\mathrm{L})$; Eragrostis plana: Pollen grain (M), detail of aperture $(\mathrm{N})$, detail of exine $(\mathrm{O})$, detail of ornamentation $(\mathrm{P})$.

\section{Pollen groups among non-native species of poaceae in southern Brazil}

Based on the pollen grain size measurements (Figure 6) of the main non-native species of Poaceae from Rio Grande do Sul, three pollen groups were proposed related to their use and cultivation in the State. The pollen grain of Zea mays, as previously described, is easily distinguished by their very large size. ${ }^{8,9}$ Pollen grains of cereal or crop species presented sizes varying from medium to large while forage species, ornamental or invasive, have pollen grains of small to 
medium size. According to the information of measurements of the pollen grains of non-native species were determinate the pollen groups of Zea mays, Secale and Briza (Table 1). The Zea mays group includes only the corn that presented pollen grain variation between 88 and $122 \mu \mathrm{m}$. On the other hand, the Secale group (35-57 $\mu \mathrm{m}$ ) includes the species Oryza sativa, Avena sativa, Avena strigosa, Secale cereale, Triticum sp. and Cenchrus clandestinus. The Briza group $(22-40 \mu \mathrm{m})$ includes pollen grains of forage, ornamental or invasive species that are: Briza minor, Holcus lanatus, Poa annua, Lolium multiflorum, Lolium temulentum, Urochloa arrecta e Eragrostis plana.

Table I Pollen groups of main non-native species of Poaceae from Rio Grande do Sul

\begin{tabular}{llll} 
Group & $\begin{array}{l}\text { Size of pollen grains } \\
\text { of group }(\boldsymbol{\mu m})\end{array}$ & Species included & Species information \\
\hline Briza & $22-40$ & $\begin{array}{l}\text { Briza minor, Holcus lanatus, Poa annua, Lolium multiflorum, Lolium } \\
\text { temulentum, Urochloa arrecta, Eragrostis plana } \\
\text { Oryza sativa, Avena sativa, Avena strigosa, Secale cereale, Triticum sp., } \\
\text { Cenchrus clandestinus }\end{array}$ & $\begin{array}{l}\text { Forage, ornamental } \\
\text { our invasive }\end{array}$ \\
Secale & $35-57$ & Zea mays & Cereal or cultivated \\
Zea mays & $88-122$ & & Corn \\
\hline
\end{tabular}

\section{Discussion}

Three pollen groups among the Poaceae pollen of non-native species of Rio Grande do Sul were obtained. However, only Zea mays can be differentiated from the native species of the State, since the pollen grains of the other non-native taxa were similar in size to the native species described. ${ }^{22-25}$ Thus, in pollen records dating from 1.000 BP to the modern age is impossible to recognize which pollen grains of native and non-native. Non-native species with welldefined dates of introduction in southern Brazil may indicate when their pollen grains may be present in Holocene quaternary sediments (Figure 7). The pollen description of non-native Poaceae species of southern Brazil was important to determine that native species of the arboreal forest of Poaceae ${ }^{22}$ have a size of pollen grains that can be identified in both past and modern pollen records. Pollen grains of species of the Bambuseae tribe have the larger size than the native species of grasslands and non-native species of the Rio Grande do Sul. ${ }^{21,22}$ Therefore, pollen grains of Bambuseae tribe can be indicative of forests in any pollen samples from southern Brazil, even after ages of the introduction of non-native grasses. Native species of grasslands can also be identified by their smaller size of the pollen grains of some $\operatorname{tax}^{22}$ in relation to non-native grasses.

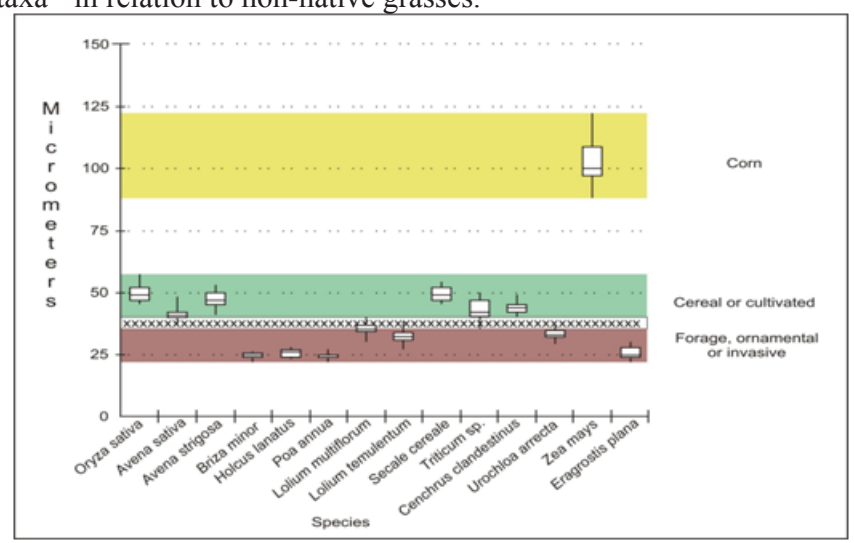

Figure 6 Box Plot of sizes of pollen grains of non-native Poaceae species from Rio Grande do Sul highlighting the pollen groups. The bold horizontal line within the box represents the median. The box shows $50 \%$ of the interquartile range, and whiskers the total variation. The marked region ( $x x x)$ shows overlap between sizes of pollen grains.

In Europe, the pollen grains of cultivated species are larger in size than the native species of this region. ${ }^{10}$ However, on the database obtained, in the Southern American continent this distinction was not possible due to the cereal species have pollen grains of similar size to the native species. The pollen grains of Oryza sativa showed similar size to that examined. ${ }^{13}$ The same occurred with Avena strigosa and Avena sativa with pollen grains previously measured ${ }^{42}$ and $^{16}$ with pollen size similar to our study. In the pollen grains of Lolium multiflorum, we observed sizes slightly larger than those measured, ${ }^{12}$ on the other hand, our measurements are similar to those obtained by ${ }^{11}$ who also described the pollen grains of this specie. While Poa annua showed pollen grains of similar size to the same species described by Salgado-Labouriau and, ${ }^{18}$ the size of the pollen grain of Triticum sp. was smaller than the size of Triticum aestivum described by the same authors. However, the measurements of Triticum sp. were similar to the sizes of the pollen grains of Triticum spelta, Triticum dicoccoides and Triticum boeoticum measured. ${ }^{10}$

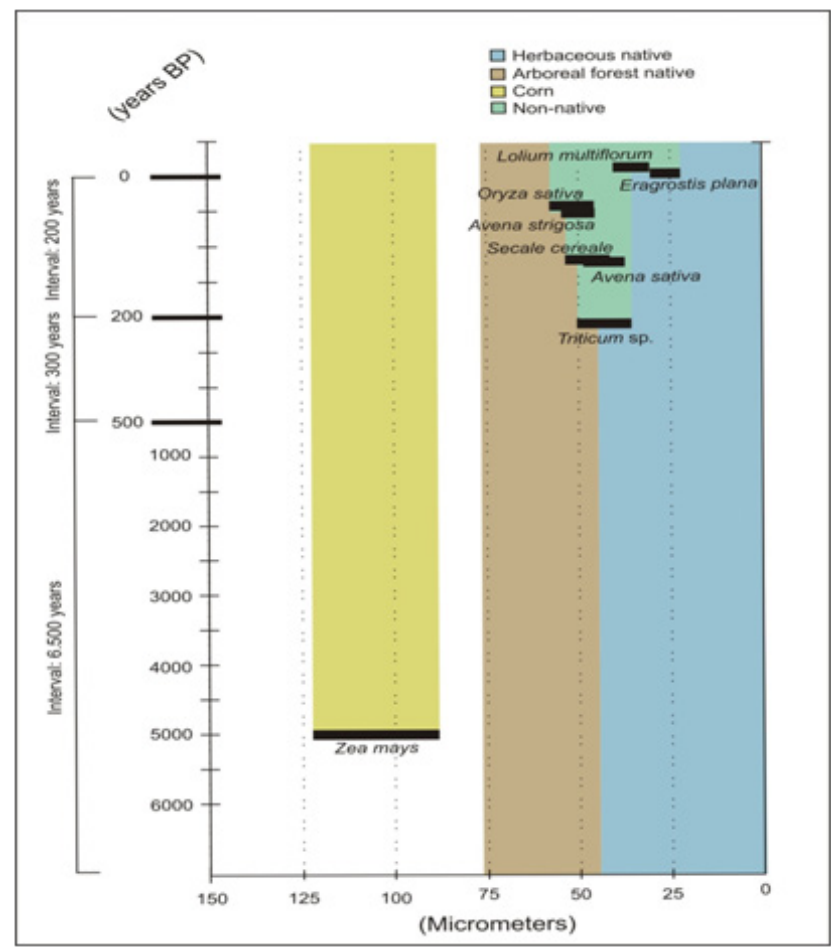

Figure 7 Chart with the dates of introduction of the non-native species of Poaceae related to the sizes of their pollen grains. Data on pollen grain sizes of native species compiled.22 Ages transformed for years before the present $=1950$. 


\section{Conclusion}

The analysis showed differences in the sizes of pollen grains between non-native species and the possibility of determining pollen groups when compared to each other. Some pollen groups are similar to the pollen grains of native species of the Poaceae family, being necessary the knowledge of the study area to affirm the diagnosis, such as the use of the area for crop cultivated or accidentally introduced species. ${ }^{43}$ verified the effects of the anthropic action on the surface samples of the municipality of Arvorezinha-RS and the information on land use associated with pollen morphology allowed the identification of pollen of Triticum (wheat). The results of this work allowed the authors to perform the first record of one non-native species of Poaceae other than corn (Zea mays) in sediments in the Rio Grande do Sul. The pollen grains of non-native species of the Poaceae family showed that the pollen grains of the Bambuseae type, which were already distinguished from native grassland species, are also distinguished from exotic species. In this way, this pollen type can be identified in Quaternary and modern palynological samples. This research confirmed that Zea mays can be used as an anthropic indicator with safety since the other exotic species of Poaceae presented pollen grains with smaller sizes. Until the present work, it was not known if other non-native grasses could have pollen of larger size. The other non-native grasses did not show different pollen morphology to native taxa and their pollen grains should be considered in pollen analyzes of the last millennium due to the impossibility of distinguish the native from non-native species in this period.

\section{Acknowledgements}

We thank Prof. Dr. Angelo Alberto Schneider from UNIPAMPA for assistance in the botanical identification of the studied species and to the ICN Herbarium by consulting the plants of Holcus lanatus, Secale cereale and Urochloa arrecta.

\section{Conflict of interest}

The authors declare that they have no conflict of interest.

\section{References}

1. Flantua SGA, Hooghiemstra H, Vuille M, et al. Climate variability and human impact in South America during the last 2000 years: synthesis and perspectives from pollen records. Climate of the Past. 2016;12:483-523.

2. Bauermann SG. Análises palinológicas e evolução paleovegetacional das turfeiras de barrocadas e Águas Claras, Planície Costeira do Rio Grande do Sul, Brasil. Ph.D. Thesis, Universidade Federal do Rio Grande do Sul, Porto Alegre; 2003. pp. 137.

3. Behling H, Pillar V, Bauermann SG. Late Quaternary Araucaria forest, grassland (Campos), fire and climate dynamics, inferred from a high-resolution pollen record of Cambará do Sul in southern Brazil. Palaeogeograph Palaeoclimatology Palaeoecology. 2004;203:277297.

4. Behling H, Pillar V, Bauermann SG. Late Quaternary grassland (Campos), gallery forest, fire and climate dynamics, studied by pollen, charcoal and multivariate analysis of the São Francisco de Assis core in western Rio Grande do Sul (southern Brazil). Review of Palaeobotany and Palynology. 2005;133:235-248.

5. Macedo RB, Souza PA, Bauermann SG, et al. Palynological analysis of a late Holocene core from Santo Antônio da Patrulha, Rio Grande do Sul, Southern Brazil. Anais da Academia Brasileira de Ciências. 2010;82(3):731-745.

6. Jeske Pieruschka V, Pillar VD, De Oliveira MAT, et al. New insights into vegetation, climate and fire history of southern Brazil revealed by a 40,000 year environmental record from the State Park Serra do Tabuleiro. Veg Hist Archaeobot. 2013;22(4):299-314.

7. Macedo RB, Souza PA, Bauermann SG. Catálogo de pólens, esporos e demais palinomorfos em sedimentos holocênicos de Santo Antônio da Patrulha, Rio Grande do Sul, Brasil. Porto Alegre, IHERINGIA, Série Botânica. 2009;64(2):43-78.

8. Salgado Labouriau ML. Contribuição à Palinologia dos Cerrados. Acad. Bras. de Ciências, Rio de Janeiro; 1973. pp. 291.

9. Morgado LN, Gonçalves Esteves V, Resendes R, et al. Pollen morphology of Poaceae (Poales) in the Azores, Portugal. Grana. 2015;54(2):282-293.

10. Joly C, Barillé L, Barreau M, et al. Grain and annulus diameter as criteria for distinguishing pollen grains of cereals from wild grasses. Review of Palaeobotany and Palynology. 2007;146(1-4):221-233.

11. Melhem TS, Cruz Barros MAV, Corrêa MAS, et al. Variabilidade polínica em plantas de Campos do Jordão (São Paulo, Brasil). Boletim do Instituto de Botânica. 2003;16:1-104.

12. Nunes RC, Bustamante FO, Techio VH, et al. Morphology and pollen viability of Lolium multiflorum Lam. Ciência e Agrotecnologia. 2012;36:180-188.

13. Chaturvedi M, Datta K, Nair PKK. Pollen morphology of Oryza (Poaceae). Grana. 1998;37:79-86.

14. Mander L, Punyasena SW. Grass pollen surface ornamentation: a review of morphotypes and taxonomic utility. Journal of Micropalaeontology. 2005;35(2):121-124.

15. Chaturvedi M, Datta K. Pollen morphology in Saccharurn L. (Poaceae) - wild and cultivated sugar cane species. Feddes Repertorium. 2001;112:387-390.

16. Nazir A, Khan MA, Abbasi AM, et al. Palynological Studies in Tribe Aveneae (Poaceae) from Potohar of Pakistan. International Journal of Sciences Basic and Applied Research. 2013;10:120-125.

17. Köhler E, Lange E. A contribution to distinguishing cereal from wild grass pollen grains by LM and SEM. Grana. 1979;18(3):133-140.

18. Salgado Labouriau ML, Rinaldi M. Palynology of Gramineae of the Venezuelan Mountains. Grana. 1990;29(2):119-128.

19. Schüler L, Behling H. Poaceae pollen grain size as a tool to distinguish past grasslands in South America: a new methodological approach. Veget Hist Archaeobot. 2011;20(2):83-96.

20. Jan F, Schüler $\mathrm{L}$, Behling $\mathrm{H}$. Trends of pollen grain size variation in $\mathrm{C}_{3}$ and $\mathrm{C}_{4}$ Poaceae species using pollen morphology for future assessment of grassland ecosystem dynamics. Grana. 2014;54(2):1-17.

21. Radaeski JN. Morfologia polínica de táxons de Poaceae do Rio Grande do Sul: uma abordagem para distinguir vegetações campestres e florestais no sul do Brasil. Masters dissertation, Universidade Federal do Pampa, São Gabriel, Brazil, 2015. pp. 85.

22. Radaeski JN, Bauermann SG, Pereira AB. Poaceae Pollen from Southern Brazil: Distinguishing Grasslands (Campos) from Forests by Analyzing a Diverse Range of Poaceae Species. Frontiers in Plant Science. 2016;7:1833.

23. Radaeski JN, Cunha DJ, Bauermann SG. Diporate Pollen Grains of Poaceae Species: High Pollen Resolution for Reconstruction 
of Grasslands Vegetation. Journal of Agricultural Research. 2017;2(3):000135.

24. Radaeski JN, Bauermann SG. Access of Dynamics Vegetation during Holocene by Poaceae Pollen Grains. Open Access Journal of Science. 2017;1(3):1-15.

25. Radaeski JN, Bauermann SG, Schneider AA, et al. Pólen de gramíneas sul-brasileiras. 1st ed. Canoas, 2017. pp. 132.

26. Bueno L, Dias A. Povoamento inicial da América do Sul: contribuições do contexto brasileiro. Estudos Avançados. 2015;29(83): 119-147.

27. Prous A, Fogaça E. Archaeology of the Pleistocene-Holocene boundary in Brazil. Quaternary International. 1999;53(54):21-41.

28. Dias A, Jacobus AL. Quão antigo é o povoamento do Sul do Brasil? Taller Internacional de INQUA La Colonización del Sur de America durante la Transición Pleistoceno/Holoceno, 2001. pp. 26.

29. Schmitz PI. Pré-História do Rio Grande do Sul. $2^{\text {a }}$ edição, Instituto Anchietano de Pesquisas, UNISINOS, São Leopoldo, 2006. pp. 164.

30. Hadler P, Dias AS, Bauermann SG. Multidisciplinary studies of Southern Brazil Holocene: Archaeological, palynological and paleontological data. Quaternary International. 2012. p.1-8.

31. Careli SS, Knierim LC. Releituras da História do Rio Grande do Sul. Fundação Instituto Gaúcho de Tradição e Folclore, 2011. pp. 282.

32. Erdtman G. Pollen Morphology and Plant Taxonomy. Angiosperms. Stockholm: Almkvist \& Wiksell; 1952.

33. Barth OM, Melhem TS. Glossário Ilustrado de Palinologia. Campinas, Editora da UNICAMP; 1988.

34. Punt W, Hoen PP, Blackmore S, et al. Glossary of pollen and spore terminology. Review of Palaeobotany and Palynology. 2007;143(12):1-81.
35. Soreng RJ, Peterson PM, Romaschenko K, et al. A worldwide phylogenetic classification of the Poaceae (Gramineae). Journal of Systematics and Evolution. 2015;53(2):117-137.

36. Boldrini II, Longhi-Wagner HM, Boechat SC. Morfologia e taxonomia de gramíneas sul-rio-grandenses. 2. ed. Porto Alegre: Editora UFRGS, 2008. pp. 87

37. Barbieri RL, Stumpf ERT. Origem e evolução de plantas cultivadas. Embrapa Informação Tecnológica, Brasília, 2008. pp. 909.

38. Schneider AA. A Flora naturalizada no Estado do Rio Grande do Sul, Brasil: Herbáceas subespontâneas. Porto Alegre Revista Brasileira de Biociências. 2007;15(2):257-268.

39. Boldrini II, Longhi-Wagner HM. Poaceae no Rio Grande do Sul: Diversidade, Importância na Fitofisionomia e Conservação. Ciência \& Ambiente. 2011;42:71-92.

40. Bianco S, Carvalho LB, Bianco MS, et al. Crescimento e nutrição mineral de Urochloa arrecta. Planta Daninha. 2015;33(1):33-40.

41. Ferreira NR, Medeiros RB, Soares GLG. Potencial alelopático do capim-annoni-2 (Eragrostis plana Nees) na germinação de sementes de gramíneas perenes estivais. Revista Brasileira de Sementes. 2008;30(2):043-050.

42. Katsiotis A, Forsberg RA. Pollen grain size in four ploidy levels of genus Avena. Euphytica. 1995;83(2):103-108.

43. Evaldt ACP, Bauermann SG, Somer J, et al. Análises integradas de amostras superficiais de município de Arvorezinha, RS, Brasil. Anais do XVI Fórum de Pesquisa Científica e Técnológica da Ulbra. 2016. 